University of Tennessee Law

Legal Scholarship Repository: A Service of the Joel A. Katz Library

UTK Law Faculty Publications

$1-2019$

Federalism, Entitlement, and Punishment across the U.S. Social Welfare State

Wendy A. Bach

Follow this and additional works at: https://ir.law.utk.edu/utklaw_facpubs

Part of the Law Commons 


\section{THE UNIVERSITY TENNEESSEE \\ KNOXVILLE}

COLLEGE OF LAW
Legal Studies

Research Paper Series

Research Paper \#391

June 2020

\title{
Federalism, Entitlement, and Punishment across the U.S. Social Welfare State
}

\author{
Wendy A. Bach
}

Transactions: The Tennessee Journal of Business Law (Forthcoming)

This paper may be downloaded without charge from the Social Science Research Network Electronic library at

http://ssrn.com/abstract $=\mathbf{3 5 5 0 1 5 9}$

Learn more about the University of Tennessee College of Law: law.utk.edu 


\section{Holes in the Safety Net}

Federalism and Poverty

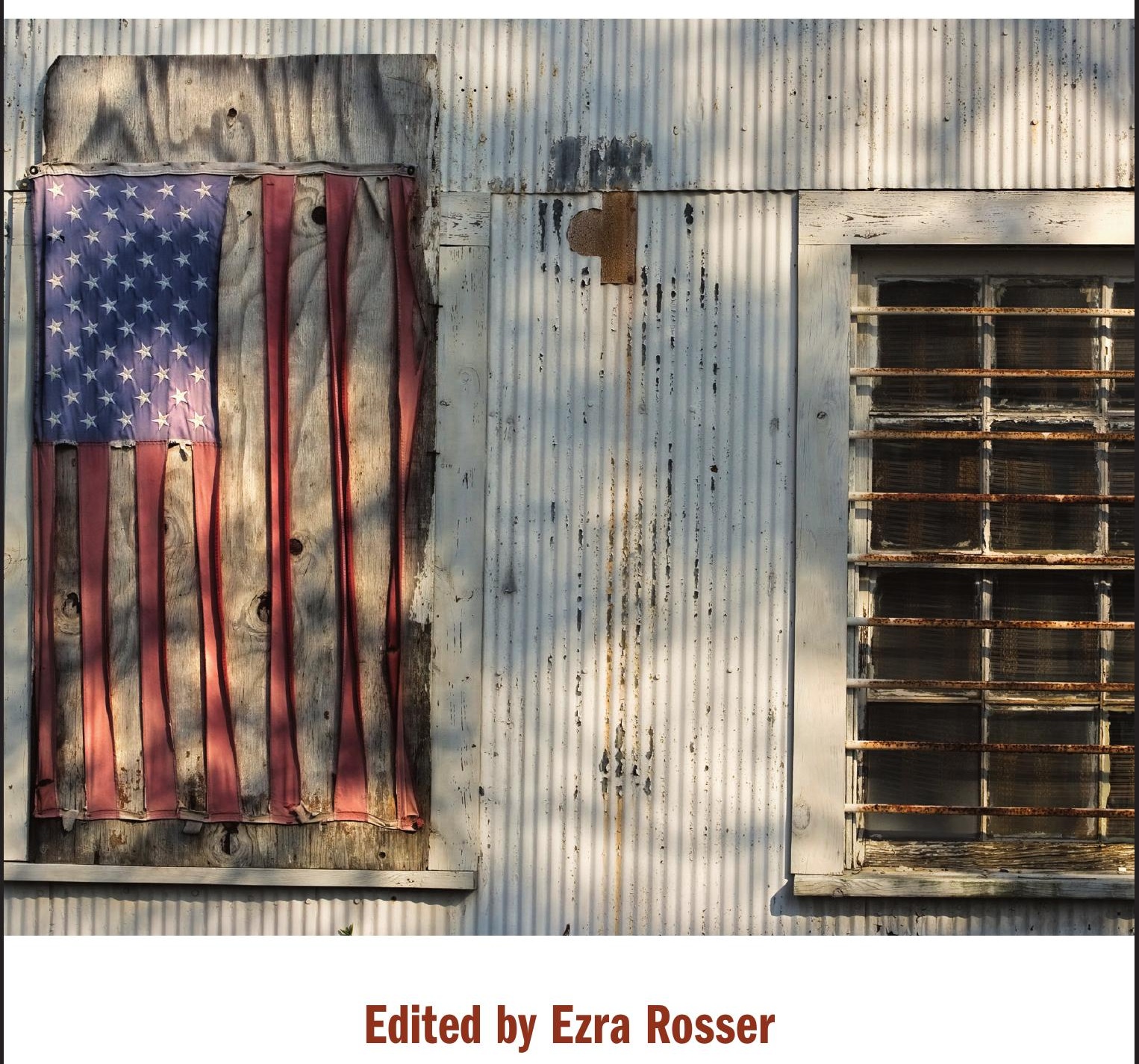




\section{HOLES IN THE SAFETY NET}

While the United States continues to recover from the 2008 Great Recession, the country still faces unprecedented inequality as increasing numbers of poor families struggle to get by with little assistance from the government. Holes in the Safety Net: Federalism and Poverty offers a grounded look at how states and the federal government provide assistance to poor people. With chapters covering everything from welfare reform to recent efforts by states to impose work requirements on Medicaid recipients, the book avoids unnecessary jargon and instead focuses on how programs operate in practice. This timely work should be read by anyone who cares about poverty, rising inequality, and the relationship between state, local, and federal levels of government.

Ezra Rosser is a law professor at American University Washington College of Law, where he teaches poverty law, property law, and federal Indian law. He is a co-author of the leading poverty law textbook and is the editor of the Poverty Law Blog. 


\title{
Holes in the Safety Net
}

\author{
FEDERALISM AND POVERTY
}

\author{
Edited by \\ EZRA ROSSER \\ American University Washington College of Law
}




\section{CAMBRIDGE UNIVERSITY PRESS}

University Printing House, Cambridge св2 8вs, United Kingdom

One Liberty Plaza, 2oth Floor, New York, NY 10006, USA

477 Williamstown Road, Port Melbourne, vIC 3207, Australia

314-321, 3rd Floor, Plot 3, Splendor Forum, Jasola District Centre, New Delhi - 110025, India

79 Anson Road, \#o6-04/o6, Singapore 079906

Cambridge University Press is part of the University of Cambridge.

It furthers the University's mission by disseminating knowledge in the pursuit of education, learning, and research at the highest international levels of excellence.

www.cambridge.org

Information on this title: www.cambridge.org/9781108475730

DOI: $10.1017 / 9781108631662$

(C) Cambridge University Press 2019

This publication is in copyright. Subject to statutory exception and to the provisions of relevant collective licensing agreements, no reproduction of any part may take place without the written permission of Cambridge University Press.

First published 2019

Printed and bound in Great Britain by Clays Ltd, Elcograf S.p.A.

A catalogue record for this publication is available from the British Library.

Library of Congress Cataloging-in-Publication Data

NAMES: Rosser, Ezra, editor.

TITLE: Holes in the safety net : federalism and poverty / edited by Ezra Rosser.

DESCRIPTION: 1 Edition. | New York : Cambridge University Press, 2019. |

Includes bibliographical references and index.

IDENTIFIERS: LCCN 2018058442 | ISBN 9781108475730 (hardback) | ISBN 9781108468848 (paperback) subjects: LCSh: Public welfare-United States. | Poverty-Government policy-United States. |

Legal assistance to the poor-United States. | Federal government-United States. |

State governments-United States. | BISAC: LAW / Constitutional.

CLASSIFICATION: LCC HV95 .H625 2019 | DDC 362.5/560973-dc23

LC record available at https://ccn.loc.gov/2018058442

ISBN 978-1-108-47573-0 Hardback

Cambridge University Press has no responsibility for the persistence or accuracy

of URLs for external or third-party internet websites referred to in this publication and does not guarantee that any content on such websites is, or will remain, accurate or appropriate. 


\section{Contents}

Introduction

Ezra Rosser

PART I：WELFARE AND FEDERALISM

$1 \quad$ Federalism, Entitlement, and Punishment across the US Social Welfare State Wendy Bach

2 Laboratories of Suffering: Toward Democratic Welfare Governance Monica Bell, Andrea Taverna, Dhruv Aggarwal, and Isra Syed

3 The Difference in Being Poor in Red States versus Blue States Michele Gilman

PART II: STATES, FEDERALISM, AND ANTIPOVERTY EFFORTS

4 States' Rights and State Wrongs: Supplemental Nutritional Assistance Program Work Requirements in Rural America Rebecca H. Williams and Lisa R. Pruitt

$5 \quad$ State and Local Tax Takeaways

Francine J. Lipman

6 Early Childhood Development and the Replication of Poverty

Clare Huntington 
7 States Diverting Funds from the Poor

Daniel Hatcher

8 States' Evolving Role in the Supplemental Nutritional

Assistance Program

David A. Super

PART III: ADVOCACY

195

9 Federalism in Health Care Reform

Nicole Huberfeld

10 Poverty Lawyering in the States

Andrew Hammond

11 Conclusion: A Way Forward

Peter Edelman

Index

255 


\title{
Federalism, Entitlement, and Punishment across the US Social Welfare State
}

\author{
Wendy Bach
}

The agency encourages "meritorious innovations that build on the human dignity that comes with training, employment and independence."

Tom Price, Secretary of Health and Human Services, and

Seema Verma, Administrator, Centers for Medicare and Medicaid Services

In the 2018 letter $^{1}$ quoted in the preceding text, the Trump administration announced that it was open to proposals to include work requirements and other changes in state Medicaid programs. These proposals came in the form of administrative waiver requests that would allow particular states the flexibility to change the rules of Medicaid eligibility in their state. They were seeking permission to condition the receipt of Medicaid on compliance with work requirements and to "align" the Medicaid program with programs like Temporary Assistance to Needy Families (TANF). The Obama administration had consistently rejected such requests on the grounds that work requirements did not further the aims of the Medicaid program, but the Trump administration felt no such qualms, likening Medicaid to TANF (colloquially welfare) and arguing that, just like welfare recipients, Medicaid recipients needed to be incentivized to work to "build" their dignity. This contest, like many others in the field of social welfare policy, plays out on the terrain of federalism. It is, on the surface, a battle over control among levels of government and over the appropriate rules and structures for particular programs. But, this chapter argues that these controversies over legal structures, legal rules, and the location of governance, are better understood as arguments about both deservingness and control played out through controversies about administrative structure. In short, programs are called "welfare," or are urged by some to be more

1 Letter from Tom Price, Secretary of Health and Human Services, and Seema Verma, Administrator of the Centers for Medicare and Medicaid Services, to state governors regarding their openness to innovation in the Medicaid Program (Mar. 14, 2017), www.hhs.gov/sites/default/ files/sec-price-admin-verma-ltr.pdf. 
like "welfare," when what is really meant is that we wish to use the administrative mechanisms of federalism to control, stigmatize, punish, and deter recipients. In contrast, when we perceive recipients as entitled, these mechanisms fall away to be replaced by purely federally controlled, far less visible, and far more inviting administrative structures. To make this process visible, this chapter describes the administrative tools of benefit programs as well as the corresponding cultural assumptions tied to each program and then contextualizes a debate like the one over Medicaid work rules using this context.

To begin, it is crucial to provide a brief theoretical background, to situate conversations about US poverty programs within a larger frame of social support across socioeconomic class, and to challenge some basic and common assumptions about who does and does not receive benefits. This chapter begins with that theoretical framework, proceeds to a (re)description of the US social welfare state to include not only poverty-based programs but also significant support programs targeted at those of substantial wealth. The chapter then demonstrates that the administrative structures of US social welfare provisions operate on a continuum from highly stigmatizing and restrictive mechanisms for the poor to nearly invisible entitlement structures for the wealthy. ${ }^{2}$ The chapter then returns to the preceding example and to the argument that these contests over rules and structure are best understood as arguments about deservingness being played out through deceptively neutral-seeming rhetoric and on the terrain of federalism and administrative law. The chapter concludes by arguing that advocates must do more than just respond to these arguments on their face (by demonstrating, for example, that the vast majority of Medicaid recipients already work). In addition, advocates must counter these moral arguments by laying bare the privileging and subordinating assumptions and mechanisms on which they are built. They must assert that, contrary to the assumptions embedded in these arguments, those in poverty, like those of means, are not people in need of our help to acquire dignity but are instead people, deserving of dignity, who should be treated accordingly.

\section{CRITICAL THEORY AND SOCIAL SUPPORT}

Critical scholarship plays a key role in describing the state's role in perpetuating and exacerbating the vast economic inequality that characterizes US society. Scholarship focused on these issues identifies ways that the state plays a role in subordinating those at the bottom and facilitating the privilege of those at the top. Not only do these analyses reveal the way that structures operate but they also reveal that arguments about legal rules (for example whether benefit programs should drug

2 This chapter is based on a more detailed presentation of these arguments in Wendy A. Bach, Poor Support/Rich Support: (Re)Viewing the American Social Welfare State, 20 FL. Tax. Rev 495 (2017) [hereinafter Bach, Poor Support/Rich Support]. Several brief passages within the chapter are taken from that text without inserting quotation marks. 
test applicants) - though presented as justified by seemingly neutral and benign ideas - are in fact deeply embedded in cultural constructs about the worthiness of those with and without economic and racial privilege.

Turning first to structurally supported subordination, a wide variety of scholars have described the way that poverty-focused support programs stigmatize, control, and punish the poor. In short, while programs like TANF and public housing do provide some support, they do so at a tremendously high cost. These mechanisms can be understood as part of what I have previously called the hyperregulatory state a set of "mechanisms of social support [that] are targeted, by race, class, gender and place, to exert punitive social control over [disproportionately] poor, AfricanAmerican women, their families and their communities."3 So, for example, conditioning welfare on drug testing both conveys the (incorrect) assumption that the poor are more likely to use drugs and exposes women to a heightened of risk of child welfare intervention. Similarly, Kaaryn Gustafson's work on the criminalization of welfare shows that programs are administered in similarly to criminal processing; ${ }^{4}$ Dorothy Roberts' scholarship shows the ways in which structures of support subordinate poor, African American women; ${ }^{5}$ and Priscilla Ocen's work highlights how community decisions to "police" Section 8 families terrorizes those poor families who had the temerity to relocate into predominantly white suburbia. ${ }^{6}$

Scholars have also laid bare how administrative structures and practices both arise from, and reinforce, deeply held social beliefs about the worthiness of poor families. Scholars like Michele Gilman ${ }^{7}$ and Ann Cammett, ${ }^{8}$ highlight the powerful role that racially coded cultural imagery of welfare has played in justifying intrusive and punitive policies aimed at poverty-based support programs. More recently, Khiara Bridges's The Poverty of Privacy Rights provides detailed and persuasive evidence that the intrusive policies that characterize welfare programs, as well as the constitutional doctrines that consistently fail to protect women from these intrusions, are grounded in cultural beliefs that poor women are fundamentally unworthy of privacy and the dignity it supports. ${ }^{9}$

3 Wendy A. Bach, The Hyperregulatory State: Women, Race, Poverty and Support, 25 Yale J. L. \& FEMINISM 319 (2014).

4 Kaaryn S. Gustafson, Cheating Welfare: Public Assistance and the Criminalization of Poverty 1 (2011).

5 See, e.g., Dorothy E. Roberts, Prison, Foster Care and the Systemic Punishment of Black Mothers, 59 UCLA L. Rev. 1474 (2012).

6 Priscilla A. Ocen, The New Racially Restrictive Covenant: Race, Welfare and the Policing of Black Women in Subsidized Housing, 59 UCLA L. Rev. 1540 (2012).

7 Michele Gilman, The Return of the Welfare Queen, 22 Am. U. J. Gender \& Soc. Pol’y \& L. 247(2014).

8 Ann Cammett, Deadbeat Dads and Welfare Queens: How Metaphor Shapes Poverty Law, 34 B.C. J. L. \& Soc. Just. 233 (2014).

9 Khiara M. Bridges, The Poverty of Privacy Rights (2017). 
The focus on the way poverty programs reinforce subordination is complemented by another body of critical scholarship focused on those with economic privilege. Our benefit structures do not simply subordinate those in poverty, they also reinforce the privilege of those at the top. Martha McClusky's scholarship on the rhetoric of neoliberalism and welfare programs is emblematic of this work. As she explains, "[N]eoliberalism embraces a racialized, genderized, and class-biased vision of social equity and community solidarity that favors the interests of the most privileged members of society." ${ }^{10}$ The state favors those interests by actively enabling the interests of privileged actors through the seemingly neutral concepts of efficiency and moral hazard. McClusky unmasks the central efficiency arguments of neoliberalism by asking a crucial question: efficient for whom? She then encourages those who defend welfare to broaden their arguments:

$[D]$ efenders of welfare should challenge the double standard underlying the neoliberal double bind, and the hierarchical vision of citizenship it both obscures and promotes. This double standard identifies some people's interests in increasing their share of the pie as part of an efficient and naturalized market that benefits the public, while others' interests in increasing their share of the pie are instead labeled redistributive, and therefore potentially harmful to the public well-being. ${ }^{11}$

As McClusky demonstrates, the idea that the provision of social welfare to the poor is "inefficient" and results in "moral hazard" is entirely dependent on whose interests are centered. If the central good being promoted is participation in the lowwage labor market, then the provision of welfare is inefficient. Welfare is both inefficient and creates a moral hazard by enabling and perhaps incentivizing recipients to stay out of the market. But if one redefines the social goal as promoting a society in which jobs provide a living wage, welfare starts to look different. By providing economic support, welfare is efficient and creates a moral benefit by strengthening the bargaining position of poor workers and incentivizing employers to provide a living wage. Turning to another example, McClusky contrasts the societal approbation for welfare with support for tax cuts for the wealthy. McClusky argues that these are moral rather than economic judgments. "By identifying welfare recipients' gains as inefficient moral hazard and tax cuts for the wealthy as promoting an efficient market, [scholars] implicitly [affirm] a citizenship vision in which the poor have subordinate moral status." ${ }^{\prime 2}$ McClusky's analysis also suggests that, rather than continuing to look solely at state structures that function to subordinate, we also need to look at the structures that elevate or sustain privilege. Heeding McClusky's call, the following section turns to this wider view of the US social welfare state.

\footnotetext{
${ }^{10}$ Martha McClusky, Efficiency and Social Citizenship: Challenging the Neoliberal Attack on the Welfare State, 78 InD. L. J. 783, 785 (2003).

${ }^{11}$ Id. at 806 .

${ }^{12}$ Id. at 832 .
} 
THE US SOCIAL WELFARE STATE: LARGER AND LESS PROGRESSIVE THAN YOU MIGHT THINK

Since at least the 1970s, a variety of scholars have sought to redefine the US social welfare state to include not only traditional benefit programs but also a variety of tax benefits that are "hidden"13 or "submerged"14 forms of "Welfare for the Wealthy."15 Including these benefits in the overall picture of US social welfare reveals a system that is larger in size than popularly believed and that distributes significant benefits regressively, to households with substantial wealth.

In popular culture, the benefits we collectively think about as "welfare" are means tested and heavily stigmatized. TANF (formerly Aid to Families with Dependent Children, or AFDC), the Supplemental Nutrition Assistance Program (SNAP, formerly food stamps), and public housing dominate the national conversation about poverty and social welfare provision. However, these programs fit but one of the three distinct categories of social welfare provision that comprise the US welfare state. The categories, for the purposes of this chapter, are (1) means-tested, nontaxbased benefits that individuals receive if they fall below a particular income threshold; (2) social insurance benefits for retirees, their spouses, and dependents, as well as for some disabled individuals; and (3) benefits - like tax expenditures, students loans, and parts of Medicare - that flow largely invisibly to individuals and families through the tax code and other support programs.

Although means-tested benefits and social insurance are the most visible forms of cash and near-cash assistance, the United States also dispenses significant financial assistance to individuals and families in other ways. These benefits have been described by Suzanne Mettler as benefits within the "Submerged State." ${ }^{16}$ Mettler contrasts visible benefits, which include both social insurance and means-tested benefits, with other benefits structured to be significantly less visible. According to Mettler, "The 'submerged state' includes a conglomeration of federal policies that function by providing incentives, subsidies, or payment to private organizations or households to encourage or reimburse them for conducting activities deemed to serve a public purpose."17

Chief among submerged state programs are tax provisions that simultaneously reduce tax collection and meet social welfare objectives. Often referred to as tax expenditures, these provisions are tax rules that are functionally identical to social

13 Christopher Howard, The Hidden Welfare State: Tax Expenditures and Social Policy in the United States 3 (1997).

14 Suzanne Mettler, The Submerged State: How Invisible Government Policies Undermine American Democracy 16-17 (2011).

15 Christopher G. Faricy, Welfare for the Wealthy: Parties, Social Spending and INEQUALity in THE United States (2015).

16 Mettler, supra note 14 , at 4.

${ }_{17}$ Id. at 4. 
welfare spending programs in that they provide a financial benefit and "promote some socially desirable objective." ${ }^{\prime 8}$ As explained by the Congressional Budget Office, "Both tax expenditures and spending programs provide financial assistance for particular activities, entities, or groups of people. Through that assistance, tax expenditures and spending programs alter people's behavior, change the allocation of resources in the economy, and transfer income among households."

The argument that legal rules, colloquially known as "tax breaks," are functionally equivalent to a welfare payment is counterintuitive. Tax breaks, so the argument goes, allow a taxpayer to "keep their own money" whereas welfare is a "handout." But from a budgetary perspective, the two are identical. Both result in a net reduction in revenue to the state and a net cash benefit to the taxpayer. As Christopher Howard explains:

$[\mathrm{W}]$ ith tax expenditures, the government is essentially collecting what taxpayers would owe under a "pure" tax system and simultaneously cutting some taxpayers a check for behaving in certain desired ways, such as buying a home. In a pure system, everyone with the same income would pay the same amount of income tax. In the real world, people with the same income often do not pay the same tax, because some are able to take advantage of tax expenditures while others are not. ${ }^{20}$

When one takes this wider view of the US social welfare state, the extent of spending appears quite different. In 2018, the US government is projected to spend approximately $\$ 560$ billion on the largest cash and near-cash benefit programs for housing, food, cash assistance, medical care, and child care. ${ }^{21}$ The United States will spend approximately $\$ 1.67$ trillion on social insurance ( $\$ 615$ billion on Medicare and $\$ 1.052$ trillion on old age and disability insurance). ${ }^{22}$ Finally in $2013,{ }^{23}$ the

${ }^{18}$ Howard, supra note 13 , at 3 .

19 Cong. Budget Office, The Distribution of Major Tax Expenditures in the Individual InCOME TAX SySTEM 8 (2013).

${ }^{20} \mathrm{Id}$.

${ }^{21}$ Office of Mgmt. \& Budget, Fiscal Year 2016 Analytical Perspectives of the US Government, at Table 25-12 (2017), www.gpo.gov/fdsys/pkg/BUDGET-2016-PER/pdf/ BUDGET-2016-PER-9-6-2.pdf (table for "Baseline Net Budget Authority by Function, Category, and Program") [hereinafter Table 25-12]. This figure includes 2018 outlays (all in millions) for Medicaid $(\$ 381,521)$; the Children's Health Insurance Program $(\$ 5,700)$; Supplemental Nutrition Assistance $(\$ 83,536)$; the Supplemental Food Program for Women, Infants and Children $(\$ 6,954)$; state child nutrition programs $(\$ 23,196)$; federally funded housing programs (\$45,440); Temporary Assistance to Needy Families $(\$ 17,347)$; Supplemental Security Income $(\$ 56,511)$; the Childcare and Development Block Grant $(\$ 2,579)$. Id. Not included in this number are transfer programs focusing on education and training, energy assistance, Veteran's benefits, programs funded to provide services to low-income individuals and communities, and some smaller mean-tested programs. Also excluded, to prevent double counting, are means-tested tax expenditures, the two most significant of which are the EITC $(\$ 62,615)$ and the CTC $(\$ 21,508)$.

${ }^{22} I d$.

${ }^{23}$ For this calculation, despite the obvious downside of using 2013 rather than 2018 data, I have chosen to use these figures because of complications involved in calculating the value of tax 
United States provided more than $\$ 900$ billion to individuals and families through the 10 largest tax expenditures. ${ }^{24}$ This figure represents approximately two-thirds of overall tax expenditure spending, roughly 5.6 percent of GDP. Clearly, inclusion of tax expenditures in the category of social welfare spending significantly affects the size of the US social welfare state.

Moreover, although benefit provision remains progressive to a certain degree, it is significantly less progressive than generally assumed. ${ }^{25}$ The three categories of social welfare programs benefit very different groups in society. The majority of meanstested benefits go to those in poverty; social insurance goes to nearly all with a progressive distribution overall. In contrast, tax expenditures flow primarily to those in the top quintiles of the economic distribution. While a small percentage of the provisions that the Congressional Budget Office deems tax expenditures benefit those in lower-income quintiles, the vast majority benefit the richest taxpayers those in the top 20 percent. For the 10 largest tax expenditures in 2013, which again totaled more than $\$ 900$ billion or 5.6 percent of GDP, "more than half of the combined benefits ... accrue to households in the highest income quintile ... with $17 \%$ going to households in the top 1 percent of the population." ${ }^{26}$ At this point it should be clear that social welfare programs exist and benefit those across the US income spectrum. But while this is true, what is also true is that these programs are structured quite differently. The following section explores those differences.

expenditures. While one can calculate outlays for direct spending programs simply by adding budget items, the calculation of tax expenditures is far more complicated. This is due to a variety of important factors. First, although one can calculate the revenue lost through a particular tax provision, this figure only represents the revenue that the state would gain if the particular provision was repealed and there were no other effects. It therefore does not account for behavioral and market changes that might result. So, for example, it does not contemplate the housing market effects on a repeal of the home mortgage interest deduction, although presumably its repeal would potentially lower market prices and/or lower the amount that a particular family spends on a home. In addition, as explained by the Congressional Budget Office, "the estimated magnitude of a collection of tax expenditures may differ from the sum of the estimate magnitudes of the separate expenditures because of the interactions that arise among expenditures." Cong. Budget Office, supra note 19, at 9. Finally, estimations "are measured relative to a comprehensive income tax system. If tax expenditures were evaluated relative to an alternative tax system ... some of the 10 major tax expenditures [included in the CBO report] would not be considered tax expenditures." Id.

24 Cong. Budget Office, supra note 19, at 1 . The 10 tax expenditures included in this analysis were exclusions for employer-sponsored health insurance, net pension contributions and earnings, capital gains on assets transferred at death, and a portion of Social Security and railroad retirement benefits; deductions including some taxes paid to state and local governments, mortgage interest payment and charitable contributions; and two tax credits, the EITC and the CTC. Id.

${ }^{25}$ For a more detailed discussion of the relative progressivity of US social welfare spending, see Bach, Poor Support/Rich Support, supra note 2.

26 Cong. Budget Office, The Distribution of Major Tax Expenditures in the Individual Income Tax System 1 (2013). 
FEDERALISM AND LEGAL AND ADMINISTRATIVE

VARIATIONS ACROSS CLASS

To lay bare the structural differences along class lines, this section focuses on two basic areas of social support: cash assistance for households with dependent children and health insurance. In the first category fall three major programs: Temporary Assistance Benefits, the Earned Income Tax Credit (EITC) and the Child Tax Credit (CTC). The second category includes a whole range of programs, two of which are the focus of this discussion: Medicaid for pregnant women and the exclusion of employer-paid health insurance premiums from taxable income. As one moves from the bottom to the top of the income scale, programs generally transition from joint federal and state administration to federal administration, from low to high participation rates, from a focus on fraud to a focus on enrolling those who are eligible, and from the presence to the absence of additional eligibility restrictions (mechanisms to scrutinize behavior and designed to share information). These examples clearly demonstrate that we have a wide variety of punitive or supportive administrative mechanisms; arguments over what rules and to impose (work requirements, for example) have everything to do with how we view the beneficiaries of a particular program and the true goals we have for it.

\section{Cash Assistance for Households with Dependent Children}

The United States provides significant income assistance to households with dependent children. For those in poverty, TANF provides the primary benefit. For those slightly higher on the income scale, the EITC provides support and for those both in the middle and at the top, the CTC plays this role. Before comparing the programs, it is important to know some basic facts about each.

The TANF program was established in 1996 to replace AFDC. In terms of income quintile, TANF serves households in the bottom quintile (the bottom fifth of the income scale). As of July 2017, families of three with no other income than TANF benefits will remain below 60 percent of the federal poverty line in every state. ${ }^{27}$ This amounts to $\$ 12,252$ in annual income. The program is authorized by federal law but administered by states through block grant funding. Participating states receive the block grant to meet loosely defined program objectives. Restrictions in federal law focus not on ensuring that poor households are supported but instead on banning assistance for certain categories of lawfully residing immigrants, forcing recipients to engage in work activities, and forbidding recipients from using certain education and training activities as a means of complying with these work

27 Ctr. for Budget and Pol'y Priorities, Policy Brief, TANF Benefits Are Too Low to Help Families Meet Basic Needs (Oct. 13, 2017), www.cbpp.org/research/family-income-support/ policy-brief-tanf-cash-benefits-are-too-low-to-help-families-meet. 
requirements. In addition, at this point, TANF is quite small, with projected 2018 expenditures totaling just more than $\$ 17$ billion. ${ }^{28}$

The EITC is a federal tax credit that can both reduce income tax liability and, in some cases, provide a benefit in excess of the tax liability. ${ }^{29}$ In contrast to TANF, it is wholly federally administered. Like TANF, the EITC is restricted to households with earned income. ${ }^{30}$ Thus, it does not provide any benefits to those in poverty who have not and/or cannot obtain work. Unlike the majority of tax expenditures, the EITC is targeted to low-income households. It phases in as earned income increases above zero and phases out as earned income/adjusted gross income increases above set thresholds. For example, for calendar year 2018 a single parent household with three or more qualifying children will not receive any EITC benefits if adjusted gross or earned income amounts exceed \$49,194 (for a married couple filing jointly with three or more dependent children the limit is $\left.\$ 54,88_{4}\right){ }^{31}$ These maximums are misleading, however, because households just below these income levels receive modest EITC benefits. EITC benefits begin to "phase out" or are reduced pro rata when adjusted gross incomes reach far lower levels. So, for example, for a single parent household with three or more children, the family will receive the maximum EITC (in $2018 \$ 6,431$ ) when earned income is at least $\$ 14,290$ and both adjusted gross income and earned income are less than $\$ 18,660$ annually. ${ }^{22}$ The EITC maximum benefit of $\$ 6,431$ plateaus between $\$ 14,290$ and $\$ 18,660$ for these families. With higher earned and adjusted gross incomes, between $\$ 18,660$ and $\$ 49,194$, the amount of the EITC phases out to zero. ${ }^{33}$ Thus the EITC provides the most benefits to lower-income households with children. The maximum childless EITC is only $\$ 519$ in $2018 .{ }^{34}$ Nevertheless, aggregate EITC benefits are quite significant in comparison to TANF. In 2017 the Internal Revenue Service (IRS) delivered \$65 billion in EITC benefits to 27 million workers and their families. ${ }^{35}$

The CTC is, like the EITC, a federal tax credit that focuses on the presence of dependent children in the taxpayer's household and, for lower-income families,

28 Office of Mgmt. \& Budget, Fiscal Year 2017 Analytical Perspectives of the U.S. Government, at Table 25-12 (2015), https://obamawhitehouse.archives.gov/sites/default/files/omb/budget/ fy2017/assets/25_12.pdf.

29 I.R.C. $\int 32$.

$3^{\circ}$ The relevant statutory provision, I.R.C. $\$ 32$, provides the credit for those with "earned income." Earned income includes all taxable income and wages received from working as well as a limited number of disability benefits received prior to retirement age. What Is Earned Income?, Internal Rev. SERv. (Dec. 16, 2016) www.irs.gov/credits-deductions/individuals/ earned-income-tax-credit/earned-income.

${ }^{31}$ I.R.C. $\$ 32$; Rev. Proc. 2018-18, 2018-10 I.R.B. 392.

${ }^{2}$ Rev. Proc. 2018-18, 2018-10 I.R.B. 392.

33 Id. For married filing jointly, the phase-out starts at $\$ 24,350$ and ends at $\$ 54,884$.

34 Internal Rev. Ser., Statistics for Tax Returns with EITC, www.eitc.irs.gov/eitc-central/statisticsfor-tax-returns-with-eitc/statistics-for-tax-returns-with-eitc.

35 Internal Rev. Ser., Statistics for Tax Returns with EITC, www.eitc.irs.gov/eitc-central/statisticsfor-tax-returns-with-eitc/statistics-for-tax-returns-with-eitc. 
requires work. As of 2018 , for most families in receipt of the credit, the CTC will provide a credit of $\$ 2,000$ per child. While the CTC does play some role in alleviating poverty, as of 2018 the credit has been changed substantially. The recent changes double the amount of the credit from $\$ 1,000$ to $\$ 2,000$ (but notably only increase the refundable portion to $\$ 1,400$ ); require a Social Security number for qualifying children; and significantly increase the phase-out thresholds for eligible households. The CTC, which previously subsidized families predominantly in the first three quintiles, ${ }^{36}$ will now benefit families with modified adjusted gross income up to and above $\$ 400,000$, well into the top quintile of earners. ${ }^{37}$ While families with incomes of $\$ 400,000$ previously would not have received any CTC benefit, as of 2018 they will receive $\$ 2,000$ per qualifying child. Many low-income families will not similarly benefit because the credit is only refundable up to $\$ 1,400$ per qualifying child and is further limited to 15 percent of earned income more than $\$ 2,500 .{ }^{3}$ As the Center on Budget and Policy Priorities, explains, because of a complicated combination of limited refundability and dependence on earned income, "[t]en million children under age 17 in low-income working families will receive nothing or a token increase of $\$ 75$ or less from the law's CTC expansion. Another 14 million children will get more than $\$ 75$ but less than the full $\$ 1$,ooo-per-child increase that families with higher incomes will receive."39

These three programs vary administratively in crucial ways. As noted in the preceding text, only TANF has joint state and federal administration. In fact, the block grant nature of the program has resulted in a degree of state discretion far broader than even other benefit programs that target the poor. As Michele Gilman makes clear in her chapter in this volume, this form of federalism has not been good for poor people. The other two programs, the EITC and the CTC, are entirely federal. They are created through federal legislation and administered by the Internal Revenue Service.

One of the primary features of benefits at the bottom is the failure of these programs to reach all those who are income eligible. TANF is particularly egregious in this respect. In 1996, when the program was created, TANF served 68 percent of families with children in poverty. But over the last two decades this has fallen precipitously. In 2017 , TANF served only 23 percent of those families. ${ }^{40}$ This decline is due in large part to the use of restrictive eligibility rules and processes. ${ }^{41}$ Moving slightly up the income scale, the EITC is far more effective, reaching 79 percent of

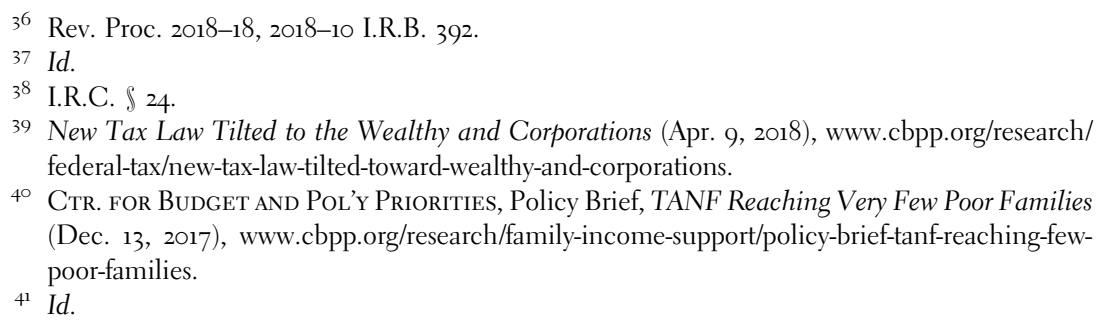


eligible households. ${ }^{42}$ Finally, while there is no available data clearly indicating participation rates for the CTC, it is fairly easy to claim on tax returns and likely has participation rates as high or higher than the EITC.

Variability in participation rates seems to arise from several factors including the definition of error used by the administering agency, the resources spent on policing error, and the application and participation rules. When discussing error rates in public assistance programs, programs diverge not on whether they are concerned with errors but on the kinds of error they are trying to avert.

Driven by the imagery of extensive "welfare fraud," agencies administering TANF focus on preventing fraud and punishing those who engage in fraud. In contrast, in more favored benefit programs, the emphasis is not on fraud but on ensuring receipt by eligible households. To accomplish these ends, agencies use diametrically opposed eligibility and error detection processes. For TANF and similar benefits, one must prove eligibility prior to receipt, not only by establishing income and resource eligibility, but also by complying with a wide swath of pre-receipt requirements. In general, no benefits are received until all requirements are met and any failure to comply (by, for example, missing one of many appointments or failing to provide documentation) can result in rejection of the application. In addition, a household found to have committed fraud faces swift and harsh punishment. In New York, for example, intentional program violations can result in denial of benefits for up to five years as well as a misdemeanor prosecution.

Tax benefits are administered quite differently. When applying for the EITC or the CTC, you simply assert eligibility by checking a box or filling out a form. Benefits are provided on the basis of that assertion. Other errors are pursued through the audit process after receipt. But even within the IRS, one can trace differences in the pursuit of fraud in the EITC versus other tax provisions. While it is true that the EITC is similar to other tax provisions in the use of the postreceipt audit process, the IRS has consistently pursued error in the EITC program more aggressively than other arguably more lucrative errors. While there is no question that the EITC erroneous payment rate is significant, "with estimates ranging from the low to high $20 \%$ range" of returns claiming the EITC, ${ }^{43}$ there is also no question that the audit rates for the EITC are very high. As Susannah Tahk explains, "[C]laiming the EITC doubles a taxpayer's chances of an audit." 44 The rationale for dedicating IRS resources to these errors, over potentially more significant sources of revenue collection, is unclear. As Nina Olsen, the National Taxpayer Advocate, points out, the cost of EITC errors is dwarfed by the cost of error in other portions of the tax code. Citing IRS data, she notes that, "EITC overclaims account for just seven

\footnotetext{
42 Natalie Holmes \& Alan Berube, The Brookings Institute, The Earned Income Tax Credit and Community Economic Stability (Nov. 20, 2015), www.brookings.edu/articles/the-earnedincome-tax-credit-and-community-economic-stability/.

43 Francine J. Lipman, Access to Tax Fnjustice, 40 PePP. L. Rev. 1173, 1193-94 (2013).

44 Susannah Tahk, The Tax War on Poverty, 56 ArIz. L. REv. 791, 844-45 (2014).
} 
percent of gross individual income tax compliance, while business income underreported by individuals accounts for $\$ 51.9 \%$," or $\$ 122$ billion in lost revenue. ${ }^{45}$ Similarly, the US Government Accountability Office has noted that the focus on the EITC is misplaced given the far larger sources of revenue potentially available if audit and collection resources were directed toward other sources of error. ${ }^{46}$ Finally, pursuing tax errors by higher-income households also yields significantly higher revenues. As Francine Lipman points out, "While less than one-quarter as many examinations were conducted of tax returns with income from $\$ 200,000$ to $\$ 1$ million, those examinations generated more tax revenue than examinations of EITC filers." ${ }^{47}$ In light of such data, it is fair to suggest that the dedication of IRS resources to the EITC, over other sources of error, represents at least in part, value judgments on the moral status of different taxpayers.

The EITC, like TANF, is characterized by severe sanctions. Taxpayers who fraudulently claim the EITC cannot receive EITC benefits for 10 years. ${ }^{4}$ Because the EITC depends on the presence of qualifying children in a taxpayer's household, the 10-year ban may effectively be a lifetime ban for a family. ${ }^{49}$ A claim made with "reckless or intentional disregard of rules" results in a two-year ban..$^{\circ}$ Although beginning in 2016 parallel sanctions applied to the CTC, ${ }^{11}$ sanctions like this are virtually unheard of in the tax code. In fact, "[t]here are no analogous sanctions applicable to other improper positions taken on federal income tax returns." ${ }^{2}$

Moving to other aspects of administration reveals additional significant differences along the income scale. In a clear feature of benefits at the bottom, applying for and receiving TANF exposes recipients to scrutiny, punitive rules, and significant risk of exposure to additional punishment. Applying for TANF involves a series of face-to-face appointments with various agency personnel. During the application process, applicants are required to disclose a wide range of personal information and

45 The National Taxpayer Advocate's 2014 Annual Report to Congress: Hearing before the Subcomm. on Gov't Operations, H. Comm. on Oversight and Gov't Reform, 114th Cong. 25 \& n. 83 (2015) (written statement of Nina E. Olson, National Taxpayer Advocate).

$4^{6}$ US Gov't Accountability Office, GaO-13-151, Tax Gap: IRS Could Significantly Increase Revenues by Better Targeting Enforcement Resources 8 (2012) (“[E]xams (both correspondence and field) of taxpayers with positive incomes of at least \$200,000 produced significantly more direct revenue per dollar of cost than exams of lower income taxpayers.").

47 Francine J. Lipman, Access to Tax friustice, 40 Pepr. L. Rev. 1173, $1193-94$ (2013).

$4^{8}$ I.R.C. $\int 32(\mathrm{k})(\mathrm{i})(\mathrm{B})(\mathrm{i})$. A similar rule was added to the CTC by the Protecting Americans from Tax Hikes Act of 2015 (PATH Act), Pub. L. No. 114-113, Div. Q, \& 208(a)(1), 129 Stat. 3040, 3083 (codified at I.R.C. $\$ 24(\mathrm{~g})$ ).

49 I.R.C. $\iint 32(\mathrm{c})(3), 152(\mathrm{c})$.

${ }^{5}$ I.R.C. $\int 32(\mathrm{k})(\mathrm{i})(\mathrm{B})(\mathrm{ii})$. A parallel rule was added to the CTC for taxable years beginning in 2016. I.R.C. $\$ 24(\mathrm{~g}) ;$ PATH Act, $\$ 208(\mathrm{c})$.

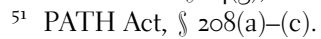

52 Lawrence Zelenak, Tax or Welfare? The Administration of the Earned Income Tax Credit, 52 UCLA L. REv. 1867, 1894 (2005); see also Lipman, supra note 36, at 1196 (quoting Zelenak). 
are subjected to extensive information-verification procedures. Failure to provide this information or documentation can result in a denial of benefits. Applicants do not receive the benefit by merely proving income eligibility. Instead, during the application process and beyond, they are subject to a wide range of nonincome- and nonasset-related criteria. Just to give a few examples, applicants are often drug tested and or required to participate in prebenefit receipt work programs. Failure to comply with any of these requirements results in denial of the application.

The process is also deeply stigmatizing. As Kaaryn Gustafson has persuasively demonstrated, "Welfare rules assume the criminality of the poor ... [and] the logics of crime control now reign supreme over efforts to reduce poverty or to ameliorate its effects." ${ }^{33}$ Practices like these are a large part of the reason that so many families in poverty do not receive help.

Benefits at the bottom are also characterized by rules limiting increases in benefits as families grow. Although as a general matter, TANF households receive higher benefits when there are more children present in the household, in many jurisdictions, this is not the case. Many states currently have "child exclusion" or "family cap" policies. These policies exclude families from receiving additional assistance if their household size increases as the result of the birth of a child. Like TANF, the EITC has both a family cap and work requirements. Prior to 1996, a family's AFDC benefit was determined by, among other factors, the size of the household. ${ }^{54}$ Each child in the household added a very small additional amount to the family's AFDC allotment. After 1996, with repeal of AFDC and enactment of TANF, states were no longer required to provide additional benefits when the household size increased. ${ }^{55}$ Since then, many states have implemented caps on budget size that do not rise upon the arrival of additional household members. ${ }^{56}$

Another central feature of TANF is its unrelenting emphasis on work. Although state and local programs had been experimenting with work programs before 1996, the TANF program instituted an aggressive national set of work requirements, requiring nearly every adult on welfare to engage in significant work activities and

53 Gustafson, supra note 4, at 1.

54 Rebekah J. Smith, Family Caps in Welfare Reform: Their Coercive Effects and Damaging Consequences, 29 HARV. J. L. \& Gender 151, 152-53 (2006) (noting that under AFDC, "states were required to obtain waivers from the federal government to implement policies such as family caps because they violated the Social Security Act by incorporating eligibility criteria based on behavior").

55 Id. at 153-54 ("The final version of TANF . . . did not require states to implement caps, but instead, by remaining silent, allowed states to continue utilizing existing family cap policies or enact new caps without federal oversight."). In fact, states were not even required to have individual benefit programs. They were merely required, as a condition of receipt of federal TANF funds, to institute programs that met the overall purposes of the federal program. Despite this latitude in federal law, all states retained some kind of cash or cash-equivalent benefit program for households with dependent children.

56 See Erika Huber et al., Welfare Rules Databook: State TANF Policies as of July 2014: OPRE Report 2015-81, at 238-39 (2015) (Table L10: Family Cap Policies, 1996-2014). 
allowing states to mete out harsh penalties for the failure to comply with these requirements. ${ }^{57}$ While there is very little evidence to suggest that these programs successfully linked TANF recipients to employment that would lift their families out of poverty, there is extensive evidence that work requirements, like other nonincome-related program criteria, resulted in widespread application denials and case closings.

Like TANF, the federal EITC contains both a family cap and a work requirement. Although the EITC increases for households with between zero and three children, it is capped at that point. Like the TANF family cap, the maximum benefit is provided to households with three "or more" children. ${ }^{58}$ Also like TANF, the EITC contains a work requirement. One can only receive the EITC if one receives work income. Families receiving equivalent incomes from other sources - for example, Social Security Disability - are not eligible for the benefit. As discussed in the following text and as noted by Dorothy Brown, ${ }^{59}$ these features are not present in the CTC, a tax expenditure program that benefits higher-income families.

Finally, applying for and participating in TANF exposes applicants to severe potential consequences. Consider Florida's drug-testing law. When implementing that law, the Florida Department of Children and Families instituted procedures that included the sharing of positive drug tests with the Florida Abuse Hotline. As described by the District Court in its decision enjoining the Florida program:

DCF shares all positive drug tests for controlled substances with the Florida Abuse Hotline.... After receiving a positive drug test, a hotline counselor enters a Parent Needs Assistance referral into a child welfare database known as the Florida Safe Families Network.... [A] referral is then prepared ... so that "other appropriate response to the referral in the particular county of residence of the applicant" may be taken.... [T] he statute governing the Florida Abuse Hotline authorizes the disclosure of records from the abuse hotline to "[c]riminal justice agencies of appropriate jurisdiction," as well as "[t]he state attorney of the judicial circuit in which the child resides or in which the alleged abuse or neglect occurred." Law enforcement officials may access the Florida Safe Families Network and make such use of the data as they see fit. ${ }^{60}$

5742 U.S.C. \& 607 (2017) (last amended 2012); see also Personal Responsibility and Work Opportunity Reconciliation Act, Pub. L. 104-193, \$103(a)(1), 110 Stat. 2105, 2129 (1996).

$5^{8}$ I.R.C. $\int 32(\mathrm{~b})(1)$.

59 Dorothy A. Brown, The Tax Treatment of Children: Separate but Unequal, 54 Emony L. J. 755, 757-58 (2005).

60 Compl. at 10, Lebron v. Wilkins, 820 F. Supp. 2d 1273 (M.D. Fla. 2011) (No. 6:11 Civ. o1473) (stating that applicants are required to sign a "Drug Testing Information Acknowledgement and Consent Release," which includes, among other provisions, that applicants consent that information on a failed test will be shared with the Florida Abuse Hotline "for review to initiate an assessment or an offer of services."). 
Moreover, in many cases, these punitive harms associated with information sharing across agencies are imposed disproportionately on African American women and their children. ${ }^{61}$

\section{Health Insurance}

The US system of health insurance includes, of course, a wide range of publicly supported programs including Medicare, Medicaid, programs created and funded through the Affordable Care Act (ACA), and various tax expenditures. This section focuses on two pieces of this puzzle: Medicaid for pregnant women as it is administered in one state and the tax exclusion for employer-provided health insurance.

New York's Prenatal Care Assistance Program (PCAP) is funded through the state's Medicaid program. Like many other poverty-targeted programs, Medicaid for pregnant mothers is enabled through federal law, jointly administered by federal and state agencies, and paid for through a combination of federal and state funds. This arrangement allows for significant flexibility for the states. For example, states have significant discretion in choosing the population of those covered, and states vary widely in the choices they make. So Oklahoma and South Dakota cover pregnant women up to 133 percent of the poverty line ${ }^{62}$ while New York covers pregnant women up to 218 percent of the poverty line. ${ }^{63}$ States also have considerable discretion in structuring their application process. ${ }^{64}$

Contrary to popular perception, even before the ACA, Medicaid and Medicare were not the only significant means through which the United States provided families with economic support for health insurance. In fact, the United States provides extensive economic support to individuals who receive their health insurance through their employers. This benefit comes in the form of the largest US tax expenditure: the exclusion of employer contributions for health care, health insurance premiums, and long-term care insurance. The way this works is fairly simple. Generally, when employers provide economic benefits to workers, those benefits must be included as earned income. Under this tax provision, employer-provided health care coverage is excluded from taxable income. So, even though the employer is providing something with economic value, that income transfer is not

61 These arguments are presented in significantly more detail in Bach, The Hyperregulatory State, supra note 3.

62 Ctr. For Medicare \& Medicaid Services, Medicaid and Chip Eligibility Levels, www .medicaid.gov/medicaid/program-information/medicaid-and-chip-eligibility-levels/index .html\#footnote4.

$6_{3} I d$.

${ }^{6}$ Matthew Diller, The Revolution in Welfare Administration: Rules, Discretion, and Entrepreneurial Government, 75 N.Y.U. L. Rev. 1121 (2000) (noting, in part, the ways in which discretion has shifted to states to manipulate the culture and organization of welfare offices). 
taxed, resulting in a net transfer of income from the federal government to the individual. In 2018, these benefits will confer almost $\$ 228$ billion in economic support to these households of employed individuals. ${ }^{6}$

While Medicaid traditionally focused on families in the lower-income quintiles, the tax exclusion of employer contributions for health care benefits higher-income families at higher rates as you move up the income scale. This is due to two primary factors: the type of employers that offer employer-sponsored health insurance and the way that tax brackets affect the value of the benefit. First, employers at the low end of the economy are simply far less likely to offer health insurance. Second, because income tax rates are progressive, that is they are higher as taxable income increases, the value of an exclusion raises as your income raises. As explained by the Tax Policy Center at the Brookings Institution, this benefit "is worth more to the higher-income families who would be more likely to purchase insurance in the first place. In 2015, less than 30 percent of families in the bottom income quintile were offered [employer-sponsored insurance, or ESI]; for them, the average benefit of the ESI exclusion was less than $\$ 10$. In contrast, nearly go percent of families in the top quintile have ESI offers and the average benefit is almost $\$ 3,200 . "$.

Like many other benefits at the bottom, the PCAP program is characterized by highly intrusive administrative structures. Khiara Bridges's ethnographic study of the PCAP program provides a detailed description of these requirements. ${ }^{67}$ As she documents, a PCAP client must provide extensive personal information to a wide variety of professionals about subjects ranging from her diet, income, history with child-welfare agencies, immigration status, mental health history, relationship history, any history of violence, use of contraception, and parenting plans - all well before she has access to this support. In a striking example of how this plays out, Bridges describes an invasive interview that took place as a part of one woman's application for prenatal assistance:

What is remarkable about this exchange is that Erica was led into a conversation about a romantic relationship that tragically involved severe, homelessnessinducing violence, the healthiness of her relationship with the father of her children, her earnings capacity, the earnings capacity of the father of her children, and any previous contact that she had had with the welfare state (in addition to answering questions about her history, if any, with tobacco and alcohol products, controlled substances, mental illness, and a host of other issues that I have not

65 U.S. Dep't of Treasury, Office of Tax Analysis, Table 3 (Oct. 16, 2017), www.treasury .gov/resource-center/tax-policy/Documents/Tax-Expenditures-FY2019.pdf (estimating the benefit at $\$ 227.88$ o billion for 2018 and $\$ 242.88$ o billion for 2019).

66 Tax Policy Center Briefing Book: Key Elements of the U.S. Tax System, www.taxpolicycenter .org/briefing-book/how-does-employer-sponsored-insurance-exclusion-affect-health-insurancecoverage.

67 Khiara M. Bridges, Privacy Rights and Public Families, 34 Harv. J. L. \& Gender 113 (2011). 
included in this excerpted portion of the interview) because she was pregnant and had presented herself to a public hospital with the hope of receiving state-assisted prenatal care. $^{68}$

Through these mechanisms, “[P] oor women's private lives are made available for state surveillance... and they are exposed to the possibility of punitive state responses." 69

The contrast between this application process and the administrative mechanisms of the employer-provided health cost exclusion is stark. The exclusion is "applied for," in the broadest sense, not by the employee who benefits but by the employer who fills out the forms. They are invisible to the beneficiaries. There are no invasive questions, no more hurdles, and no possibility of further punitive intervention. Instead there is only financial support.

\section{VISIBILITY, INVISIBILITY, AND ENTITLEMENT}

Clearly, the United States provides government benefits to individuals along the entire income spectrum. This chapter has highlighted this phenomenon in the realms of cash assistance to households with dependent children and health insurance, but the observation holds true across the US social welfare state. While benefits for the poor are visible, stigmatizing, and punitive, benefits for those with means are largely invisible. This invisibility is embedded in the structure of those programs. As Suzanne Mettler explains, the "[H]allmark [of submerged state benefits] is the way they obscure government's role from the view of the general public, including those who number among their beneficiaries. Even when people stare directly at these policies, many perceive a freely functioning market system at work." 70

If one accepts the premise that these are all social welfare benefits, given by the state to individuals for similar needs (medical care or support of dependent children), then the differences in administration cannot have anything to do with the best or the most efficient administrative mechanism to provide support for dependent children or for health care. Instead, it must have something to do with the recipients. The message is clear: benefits for the nonpoor are not a handout. Recipients of benefits like the CTC and the health insurance premium exemption are entitled to those benefits. There is nothing wrong with these beneficiaries and nothing we need to change about them connected to receipt of the benefit. Unlike the women applying for PCAP, there is no need to ask about their life circumstances, relationships, or plans. For the PCAP recipient, we seem to assume that she needs more than just the prenatal care that she is seeking. Perhaps she has a problem

\footnotetext{
68 Id. at 116.

69 Id. at 131 .

70 Mettler, supra note 10, at 5 .
} 
with her relationships or her finances. Read in the most generous light, the invasive questions indicate a desire to help with the problems that we assume she has. Read less generously, and perhaps more accurately, we mean instead to shame and deter her. If this is generosity, it is at best generosity inextricable from bias. What is crucial is that we assume she has those problems and is in need of help when we make no such assumptions for recipients of the CTC or the health insurance premium exemption. Unlike the poor and stereotypically black recipients of PCAP or TANF, recipients of those tax benefits are not dependent and therefore do not need to be taught independence. They are not likely drug users. They are not likely frauds. They are not likely criminals. But that is not the case for our image of the poor. Despite the fact that the vast majority of support for the poor goes to white families, our image remains that of the welfare queen. It is only if one accepts these assumptions that the structural differences highlighted in this chapter make sense.

\section{MEDICAID WAIVER REQUESTS}

In 2017, the Trump administration, while failing to lead their party to the repeal of the ACA, turned some of its energy to wielding an administrative mechanism to make significant changes to the Medicaid program. The administration used a provision in federal law allowing them to grant waiver requests (called 1115 waivers) to states to do demonstration projects that test new approaches to meeting programmatic aims. Several states proposed changes that sought to align the Medicaid program more closely, as a matter of administration, with programs like TANF and SNAP. States sought waivers to include work requirements, drug screening, and eligibility time limits on the program, all hallmarks of the 1996 welfare reform.

While similar requests had been pending for some time with the Department of Health and Human Service's Centers for Medicare and Medicaid Services (CMS), a letter from Tom Price and Seema Verma, quoted at the opening of this chapter, gave significant cause for hope to those states seeking these waivers. At the start of the letter, Price and Verma provided their justification for this new willingness to consider waiver requests, "The expansion of Medicaid through the Affordable Care Act (ACA) to non-disabled, working age adults without dependent children was a clear departure from the core, historical mission of the program." The ACA - which provided, for the first time, Medicaid coverage for individuals below 133 percent of the poverty level who were not pregnant, disabled, or the parent or caretaker of a dependent child - had changed the rules of the game. For Price and Verma, these recipients were not the "truly vulnerable." Instead, their presence called, by this line of thinking, for a different kind of Medicaid program. The letter went on to encourage states to experiment with work requirements that would "build on the human dignity that comes with training, employment and independence." What is interesting about this framing is the focus on dignity. Although states have certainly sought waivers not just for this population, these new recipients lacked human 
dignity; to obtain it, they needed a set of administrative rules that provide human dignity for them. The stereotype that poor Medicaid recipients are people not worthy of being treated as already possessing dignity justified the policy.

Several months later, in a letter to State Medicaid Directors from CMS, the agency counseled states that, in implementing work requirements, "CMS supports states' efforts to align SNAP or TANF work or work-related requirements with the Medicaid program as a part of a demonstration authorized under section 1115." ${ }^{71}$ While there is an ostensibly benign reason for this suggestion (an individual receiving multiple benefits should be subject to just one uniform work requirement), another clear message comes through. The attempt embodied in the ACA to create an entitlement to health care for all, including nondisabled poor individuals without dependents, sent the wrong message. Work requirements, like drug testing, and time limits are hallmarks of benefits for the poor and are heavily racially coded. They assume that the poor, unlike the wealthy, are in need of behavioral control. They assume that poor people are in need of our teaching. And we know this because we have other administrative mechanisms at our disposal that we choose not to use. When we provide the CTC or the exemption for health care expenses or a whole list of other benefits for the wealthy, nothing about how we provide those benefits suggests the same set of assumptions. Instead, we signal through our means of administration that wealthy recipients are worthy and entitled to benefits.

\section{CONCLUSION}

At the end of the day as advocates, we must continue to make arguments on the merits that respond to proposals presented by those who deem the poor unworthy. In the Medicaid example, we must continue to demonstrate that the vast majority of Medicaid recipients already work and that - if the TANF experience is a guide - the impact of these changes will not be to transition families to work that sustains their families, but instead will simply diminish the number of those in receipt of the benefit. Beyond this, we cannot stop reminding the public of two essential facts. First, that the poor, like those of means, do not need a program to give them dignity. What they need and deserve instead are programs that provide support and that treat them with dignity. Second, for those who suggest that these programmatic elements are the best or most efficient way to run support programs, we must lay bare their assumptions and remind them that we already have the tools at our disposal to treat the poor with dignity. We do so for the rich every day.

${ }^{71}$ Dep't of Health \& Human Services, State Medicaid Director Advisory Letter, Opportunities to Promote Work and Community Engagement among Medicaid Beneficiaries (Jan. 11, 2018), www.medicaid.gov/federal-policy-guidance/downloads/smd180o2.pdf. 